Supporting information for:

\title{
Surveying manganese oxides as electrode materials for harnessing salinity gradient energy
}

Jenelle Fortunato, ${ }^{a}$ Jasquelin Pena, ${ }^{b}$ Sassi Benkaddour, ${ }^{b}$ Huichun Zhang, ${ }^{\mathrm{c}}$ Jianzhi Huang, ${ }^{\mathrm{c}}$ Mengqiang Zhu, ${ }^{d}$ Bruce E. Logan, ${ }^{a}$ and Christopher A. Gorski ${ }^{*}, \mathrm{a}$

a Department of Civil and Environmental Engineering, The Pennsylvania State University, University Park, Pennsylvania, 16802, United States

bDepartment of Geoscience and Environment, University of Lausanne, CH-1015, Lausanne, Switzerland

c Department of Civil Engineering, Case Western Reserve University, Cleveland, Ohio, 44106, United States

${ }^{\mathrm{d}}$ Department of Ecosystem Science and Management, University of Wyoming, Laramie, Wyoming, 82071, United States

*Corresponding Author: cag981@psu.edu; Phone: +1-814-865-5673

Pages: 18

Figures: 8

Tables: 1 


\section{Section S1. Manganese oxide syntheses}

$\beta-\mathrm{MnO}_{2}-1\left(\mathrm{SSA}=4.72 \pm 0.02 \mathrm{~m}^{2} / \mathrm{g}\right)$ was synthesized via hydrothermal synthesis using an established method from literature. ${ }^{1}$ The initial mixture was stirred in a beaker for 20 min, then transferred to a Teflon-lined hydrothermal autoclave reactor (model: CIT-HTC230-V200; Col-Int Tech, Irmo, SC, USA) and placed in a muffle furnace at $120^{\circ} \mathrm{C}$ for $24 \mathrm{~h}$. The resulting mixture was cooled to room temperature naturally. The sample was washed by centrifugation ( $259 \mathrm{rcf}, 10 \mathrm{~min})$, discarding the supernatant, and resuspending the pellet in fresh DI water. The wash step was repeated until the supernatant was clear and the $\mathrm{pH}$ was near neutral, then the pellet was dried in a vacuum oven $\left(55^{\circ} \mathrm{C}, 12 \mathrm{~h}\right) \cdot \beta-\mathrm{MnO}_{2}-2 \quad\left(\mathrm{SSA}=14.4 \pm 0.1 \mathrm{~m}^{2} / \mathrm{g}\right)$ was synthesized from a previously described protocol. ${ }^{2,3}$ Separate solutions of $\mathrm{KMnO}_{4}(0.2528 \mathrm{~g})$ and $\mathrm{MnCl}_{2}(0.475 \mathrm{~g})$ were prepared by dissolving the salts in $10 \mathrm{~mL}$ DI water. The two solutions were combined, stirred for $1 \mathrm{~h}$, and transferred to a Teflon-lined autoclave to heat at $180{ }^{\circ} \mathrm{C}$ for $48 \mathrm{~h}$. The resulting product was filtered, and subsequently washed with DI water several times. The solid was dried in air at $180^{\circ} \mathrm{C}$ for $18 \mathrm{~h}$.

$\mathrm{Mn}_{2} \mathrm{O}_{3}\left(\mathrm{SSA}=21.91 \pm 0.06 \mathrm{~m}^{2} / \mathrm{g}\right)$ nanopowder was purchased commercially from US Research Nanomaterials, Inc (Houston, TX).

$\gamma-\mathrm{MnO}_{2}\left(\mathrm{SSA}=40.78 \pm 0.08 \mathrm{~m}^{2} / \mathrm{g}\right)$ was synthesized using an acid-digestion protocol adopted from Walanda et al. (2009). ${ }^{4}$ While stirring, $5.0 \mathrm{~g}$ of $\mathrm{KMnO}_{4}$ was added to $50 \mathrm{~mL}$ of $1 \mathrm{M}$ $\mathrm{H}_{2} \mathrm{SO}_{4}$ that was preheated to $80^{\circ} \mathrm{C}$ in a two- neck round bottom flask fitted with a Graham Condenser. Cold tap water flowed through the condenser column while the mixture incubated for three days at $80^{\circ} \mathrm{C}$ under stirring. The sample was subsequently washed by centrifugation (259 rcf, $10 \mathrm{~min}$ ), discarding the supernatant, and resuspending the pellet in fresh DI water. The wash step was repeated several times until the $\mathrm{pH}$ was near neutral then dried in a vacuum oven $\left(55^{\circ} \mathrm{C}, 12 \mathrm{~h}\right)$.

$\alpha-\mathrm{MnO}_{2}\left(\mathrm{SSA}=177.3 \pm 0.7 \mathrm{~m}^{2} / \mathrm{g}\right)$ was synthesized using an established method from literature. ${ }^{2,5}$ A mixture of $9 \mathrm{mmol} \mathrm{Mn}(\mathrm{Ac})_{2} \cdot 4 \mathrm{H}_{2} \mathrm{O}$ and $6 \mathrm{mmol} \mathrm{KMnO}_{4}\left(\mathrm{Mn}^{2+}: \mathrm{Mn}^{7+}=3: 2\right)$ was homogenized with an agate mortar for $30 \mathrm{~min}$. The mixture was transferred to a glass vial, 
capped, and heated at $120^{\circ} \mathrm{C}$ for $4 \mathrm{~h}$. The resulting solid was cooled, washed several times, and dried overnight in air at $80^{\circ} \mathrm{C}$.

Potassium birnessite $\left(\mathrm{KBi}, \mathrm{SSA}=7.21 \pm 0.03 \mathrm{~m}^{2} / \mathrm{g}\right)$ was synthesized by pyrolyzing $\mathrm{KMnO}_{4}$ that was ground in a mortar with a pestle and spread to a $1 \mathrm{~mm}$ thick layer. The sample was held at $800^{\circ} \mathrm{C}$ for $5 \mathrm{~h}$ with a $1^{\circ} \mathrm{C} / \mathrm{min}$ heating ramp and cooled naturally. The powder was then washed with excess DI water and freeze-dried for $15 \mathrm{~h}$.

Triclinic sodium birnessite $\left(\mathrm{TCNaBi}, \mathrm{SSA}=28 \pm 1 \mathrm{~m}^{2} / \mathrm{g}\right)$ was synthesized using an established method from literature. ${ }^{6}$ The synthesis involves the oxidation $\mathrm{MnCl}_{2}$ in $\mathrm{NaOH}$ under oxygen flow to precipitate buserite, which was then collapsed to triclinic sodium birnessite with drying. In a $1 \mathrm{~L}$ wide-neck Erlenmeyer flask, $200 \mathrm{~mL}$ of $0.5 \mathrm{M} \mathrm{MnCl}_{2}$ was stirred vigorously using a paddle stirrer and bubbled with oxygen at a flow rate of $2-4 \mathrm{~L} / \mathrm{min}$ (1.5 bar). A $250 \mathrm{~mL}$ aliquot of $5.5 \mathrm{M} \mathrm{NaOH}$ was added quickly to the reaction flask and the solution was allowed to mix and oxygenate for $5 \mathrm{~h}$. After mixing, the solution was centrifuged at $6000 \mathrm{rpm}$ for $20 \mathrm{~min}$ and the supernatant was discarded. To wash the sample, the pellet was resuspended in approximately $650 \mathrm{~mL}$ of DI water, centrifuged (6000 rpm, $20 \mathrm{~min})$, and the supernatant was discarded. This procedure was repeated until the supernatant $\mathrm{pH}$ was approximately 9 (about 10 washes).

Hexagonal birnessite $\left(\mathrm{HexBi}, \mathrm{SSA}=29.0 \pm 0.2 \mathrm{~m}^{2} / \mathrm{g}\right)$ was synthesized by modifying the method of McKenzie (1971). ${ }^{7}$ Briefly, $45 \mathrm{~mL}$ of $6 \mathrm{M} \mathrm{HCl}$ was added dropwise using a peristaltic pump (approximately $20 \mathrm{drops} / \mathrm{min}$ ) to a $500 \mathrm{~mL}$ round-bottom flask containing $300 \mathrm{~mL}$ of 0.76 $\mathrm{M} \mathrm{KMnO}$. The flask was immersed in an oil bath maintained at $110^{\circ} \mathrm{C}$ and the $\mathrm{KMnO}_{4}$ solution was refluxed to minimize the evaporation of $\mathrm{HCl}$ and water. The dark purple $\mathrm{KMnO}_{4}$ solution turned brown upon the dropwise addition of $\mathrm{HCl}$. After $\mathrm{HCl}$ addition, the slurry was allowed to boil for $20 \mathrm{~min}$, then cooled naturally to $60^{\circ} \mathrm{C}$, and aged in an oven for $16 \mathrm{~h}$ at $60^{\circ} \mathrm{C}$. The product was washed five times using deionized water and dialyzed for two days, at which point the electrical conductivity decreased to $34.2 \mu \mathrm{S} / \mathrm{cm}$.

$\delta-\mathrm{MnO}_{2}-1\left(\mathrm{SSA}=155.3 \pm 0.3 \mathrm{~m}^{2} / \mathrm{g}\right)$ was synthesized using the following redox reaction and a $0.67 \mathrm{KMnO}_{4}: \mathrm{MnCl}_{2}$ ratio to precipitate poorly crystalline nanoparticulate $\mathrm{MnO}_{2}$ :

$$
2 \mathrm{KMnO}_{4}+3 \mathrm{MnCl}_{2}+4 \mathrm{NaOH}=5 \mathrm{MnO}_{2}+2 \mathrm{KCl}+4 \mathrm{NaCl}+6 \mathrm{H}_{2} \mathrm{O}
$$


Briefly, $300 \mathrm{~mL}$ of $0.2 \mathrm{M} \mathrm{KMnO}_{4}$ was added to $240 \mathrm{~mL}$ of $0.49 \mathrm{M} \mathrm{NaOH}$ solution using a peristaltic pump at a flow rate of $256 \mathrm{~mL} / \mathrm{min}$, while the solution was stirred vigorously. Following the $\mathrm{KMnO}_{4}$ addition, $300 \mathrm{~mL}$ of $0.3 \mathrm{M} \mathrm{MnCl}_{2}$ solution was added to the mixture using a peristaltic pump (36 mL/min) and the completed mixture was allowed to stir for $10 \mathrm{~min}$. After a settling period of $30 \mathrm{~min}$, the supernatant was removed and the sample was washed by centrifugation with DI water until a pH of about 6 and a conductivity of $17.7 \mu \mathrm{S} / \mathrm{cm}$ was achieved.

$\delta-\mathrm{MnO}_{2}-2\left(\mathrm{SSA}=217.2 \pm 0.3 \mathrm{~m}^{2} / \mathrm{g}\right)$ was synthesized via benchtop redox using an established method from literature. ${ }^{8}$ Briefly, $750 \mathrm{~mL}$ of $0.15 \mathrm{M} \mathrm{Mn}\left(\mathrm{NO}_{3}\right)_{2}$ was pumped (10 $\mathrm{mL} / \mathrm{min}$ ) into a $750 \mathrm{~mL}$ solution containing $0.1 \mathrm{KMnO}_{4}$ and $0.2 \mathrm{NaOH}$, while stirring. After addition, the reaction mixture aged to $20 \mathrm{~h}$ under stirring, then the suspension was precipitated gravitationally and the supernatant discarded. The remaining slurry was dialyzed against DI water $(18.2 \mathrm{M} \Omega \mathrm{cm})$ for 9 days at which point the conductivity reached $11.7 \mu \mathrm{S} / \mathrm{cm}$. The resulting slurry was stored in DI water at $4{ }^{\circ} \mathrm{C}$ until use.

$\delta-\mathrm{MnO}_{2}-3\left(\mathrm{SSA}=314.1 \pm 0.8 \mathrm{~m}^{2} / \mathrm{g}\right)$ was synthesized via benchtop redox using an established method from literature. ${ }^{1}$ by adding $1.25 \mathrm{~g}$ of $\mathrm{KMnO}_{4}$ and $2.02 \mathrm{~g}$ of $\mathrm{MnSO}_{4} \cdot \mathrm{H}_{2} \mathrm{O}$ to 100 $\mathrm{mL}$ of DI water, which was stirred overnight at room temperature. The dark brown precipitate was then washed by centrifuging the sample (259 rcf, $10 \mathrm{~min}$ ), discarding the supernatant, and resuspending the pellet in fresh DI water. The washing step was repeated until the supernatant was clear and the $\mathrm{pH}$ was near neutral, then the pellet was dried in a vacuum oven $\left(55^{\circ} \mathrm{C}, 12 \mathrm{~h}\right)$. Sodium manganese oxide $\left(\mathrm{NMO}, \mathrm{SSA}=2.20 \pm 0.02 \mathrm{~m}^{2} / \mathrm{g}\right)$ was synthesized via solid-state reaction using an established method from literature. ${ }^{9-11}$ Briefly, a 0.55:1 mixture of $\mathrm{Na}_{2} \mathrm{CO}_{3}(58.29$ g) and $\mathrm{Mn}_{2} \mathrm{O}_{3}(157.87 \mathrm{~g}$ ) was homogenized with a mortar pestle and subsequently ball milled (Norton Chemical Process Products Division, Akron, OH) for $2 \mathrm{~h}$. The powdered mixture was calcined in a box furnace (CWF 12/5 Chamber Furnace, Carbolite Gero) held at $750{ }^{\circ} \mathrm{C}$ for $8 \mathrm{~h}$ with a heating ramp of $5{ }^{\circ} \mathrm{C} / \mathrm{min}$. The solid was allowed to cool to room temperature naturally, then ground with mortar pestle and passed through a $45 \mu \mathrm{m}$ sieve for subsequent use. 

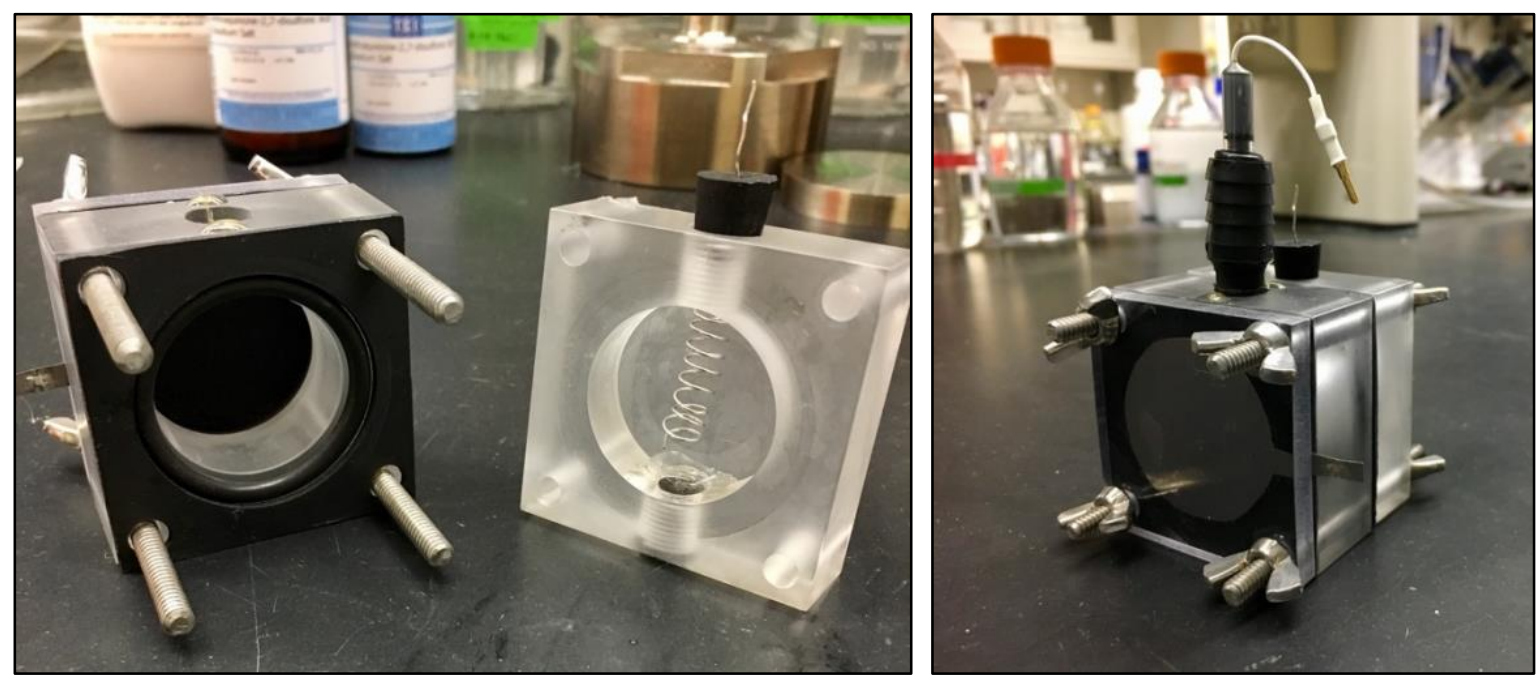

Figure S1. The custom built 3-electrode cell used to perform electrochemical tests. The reactor was assembled with a $\mathrm{Ag} / \mathrm{AgCl}$ reference electrode $(3 \mathrm{M} \mathrm{KCl})$, a platinum curly wire counter electrode, and titanium foil current collector.

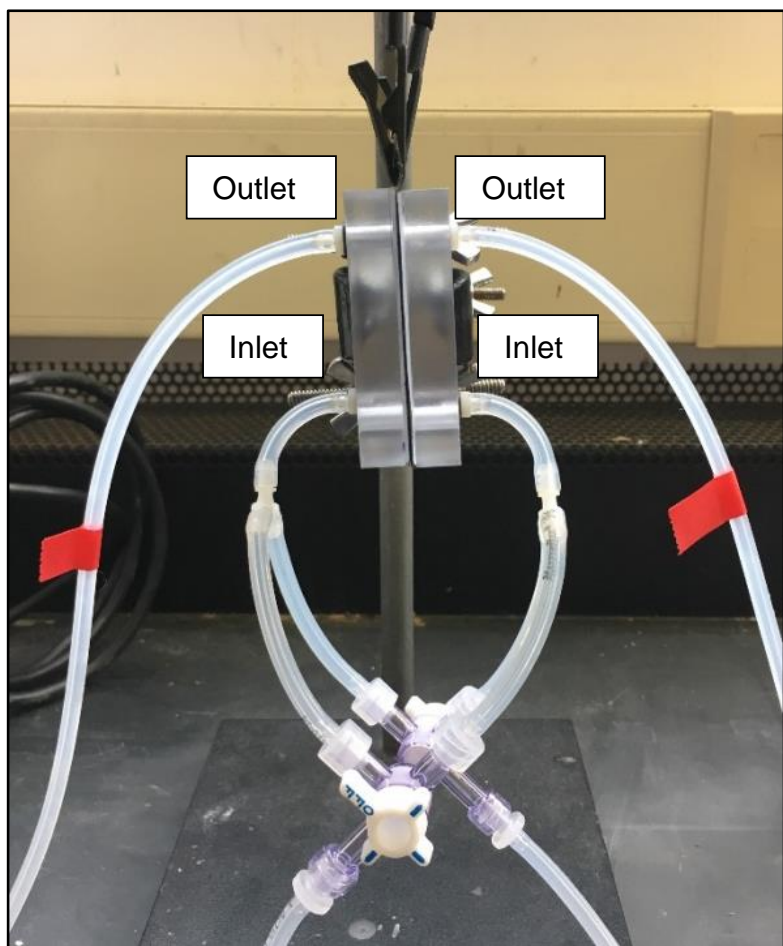

Figure S2. Setup for salinity gradient energy concentration flow cell showing inlets and outlets. Reactor body dimensions: $60 \mathrm{~mm}$ X $60 \mathrm{~mm}$ x $10 \mathrm{~mm}$; spacer gaskets create rectangular flow paths (width = $1 \mathrm{~cm}$; height $=3 \mathrm{~cm}$; thickness $\approx 120 \mu \mathrm{m}$ ); and flow channels were separated by an anion exchange membrane (thickness $\approx 150 \mu \mathrm{m}$ ). 
Table S1. Material characterization, capacity, and salinity gradient energy data for manganese oxide electrodes

\begin{tabular}{|c|c|c|c|c|c|c|c|c|}
\hline Manganese oxidea & $\begin{array}{c}\text { Tunnel } \\
\text { structureb }\end{array}$ & $\begin{array}{l}\text { Sizeb } \\
(\AA)\end{array}$ & $\begin{array}{c}\text { BET SSA } \\
\left(\mathrm{m}_{2} / \mathrm{g}\right)\end{array}$ & $\begin{array}{l}\text { Specific } \\
\text { Capacityc } \\
\text { (F/g) }\end{array}$ & $\begin{array}{l}\text { Specific } \\
\text { Capacityc } \\
(\mathrm{mA-h} / \mathrm{g})\end{array}$ & $\begin{array}{l}\text { Avg Power } \\
\text { Density } \\
\left(\mathrm{W} / \mathrm{m}_{2}\right)\end{array}$ & $\begin{array}{c}\text { Peak } \\
\text { Power } \\
\text { Density } \\
\left(\mathrm{W} / \mathrm{m}_{2}\right)\end{array}$ & $\begin{array}{c}\text { External } \\
\text { Resistanced } \\
(\Omega)\end{array}$ \\
\hline$\beta-\mathrm{MnO}_{2}-2$ & $(1 \times 1)$ & 1.89 & $14.4 \pm 0.1$ & 24.5 & 4.08 & $0.036 \pm 0.002$ & 0.06 & 50 \\
\hline $\mathrm{Mn}_{2} \mathrm{O}_{3}$ & $\mathrm{~N} / \mathrm{A}$ & $\mathrm{N} / \mathrm{A}$ & $21.91 \pm 0.06$ & 45.8 & 7.64 & $0.078 \pm 0.004$ & 0.14 & 40 \\
\hline Potassium Birnessite & \multirow{3}{*}{$\begin{array}{l}\text { Layered } \\
\text { sheets }\end{array}$} & \multirow{3}{*}{7.0} & $7.21 \pm 0.03$ & 85.2 & 14.2 & $0.207 \pm 0.007$ & 0.43 & 40 \\
\hline Triclinic Sodium Birnessite & & & $28 \pm 1$ & 299 & 49.8 & $0.538 \pm 0.006$ & 0.22 & 20 \\
\hline Hexagonal Birnessite & & & $29.0 \pm 0.2$ & 311 & 51.8 & $0.72 \pm 0.03$ & 1.39 & 10 \\
\hline$\delta-\mathrm{MnO}_{2}-1$ & $\begin{array}{l}\text { Layered } \\
\text { Sheets }\end{array}$ & 7.0 & $155.3 \pm 0.3$ & 219 & 36.5 & $0.445 \pm 0.006$ & 1.02 & 20 \\
\hline
\end{tabular}

aColor coding in the Manganese oxide column groups samples of the same crystal structure.

b Manganese oxide phases were confirmed with XRD and tunnel structures and sizes were derived from literature for each confirmed phase.

c Specific capacity calculated from cyclic voltammetry at $5 \mathrm{mV} / \mathrm{s}$ scan rate in $1 \mathrm{M} \mathrm{NaCl}$.

d The external resistance used during salinity gradient energy concentration flow cell experiments.

e No power measurement was recorded because cell voltage never exceeded the cutoff voltage of $\pm 30 \mathrm{mV}$ 

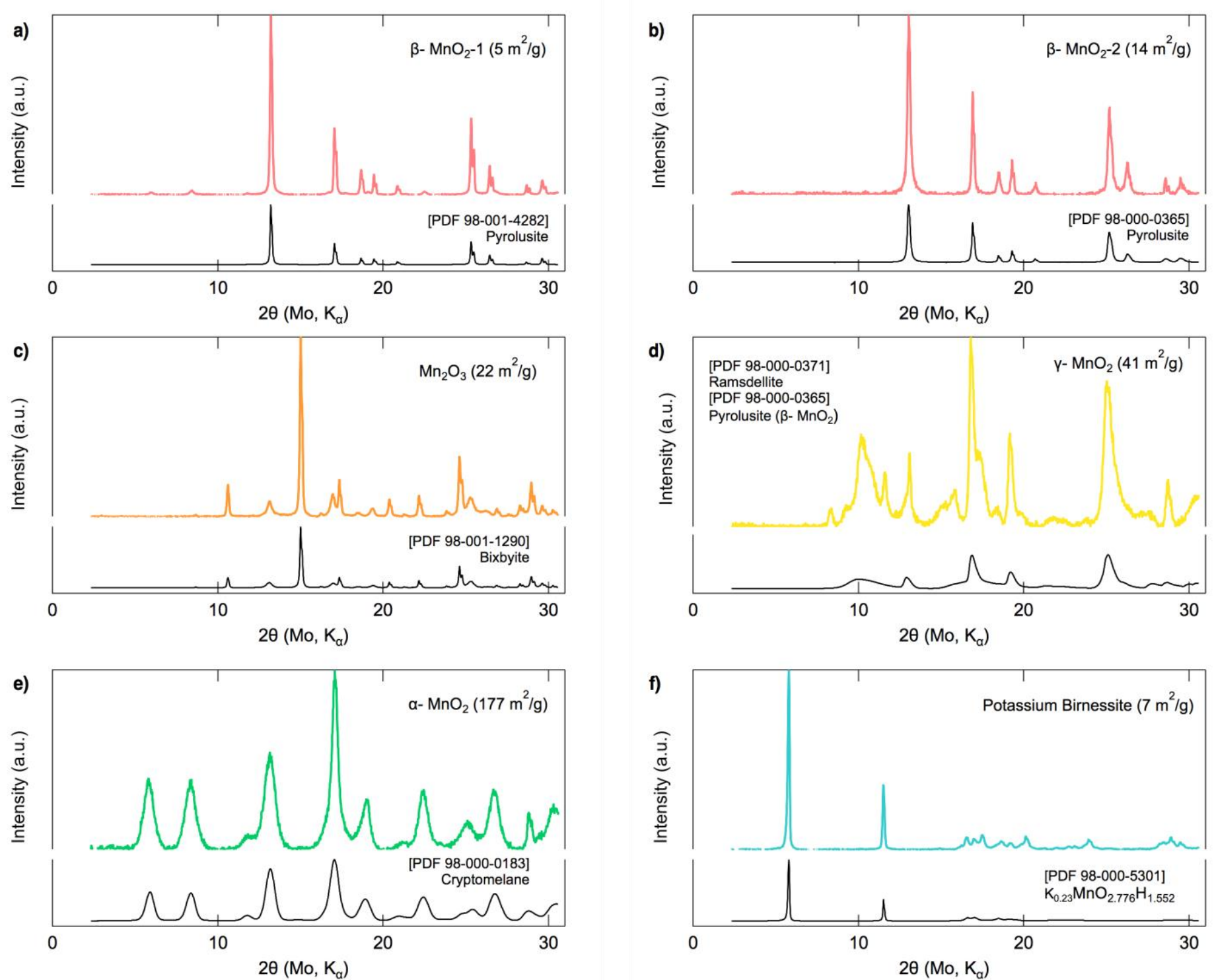

Figure S3. Powdered X-ray diffraction ( $\mathrm{XXRD}$ ) patterns for manganese oxide samples. 

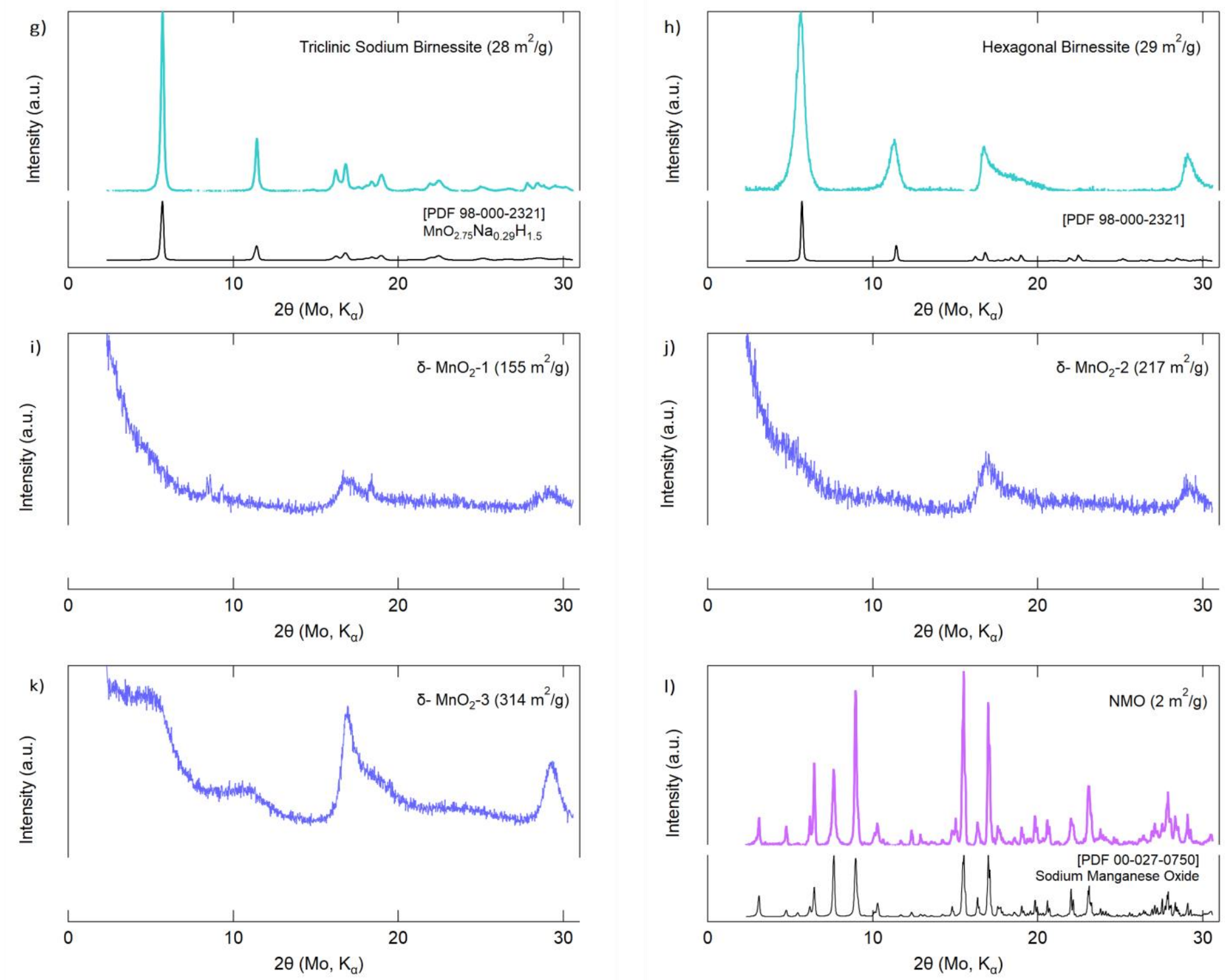

Figure S3 (continued). Powdered X-ray diffraction ( $\mathrm{XRR}$ ) patterns for manganese oxide samples 

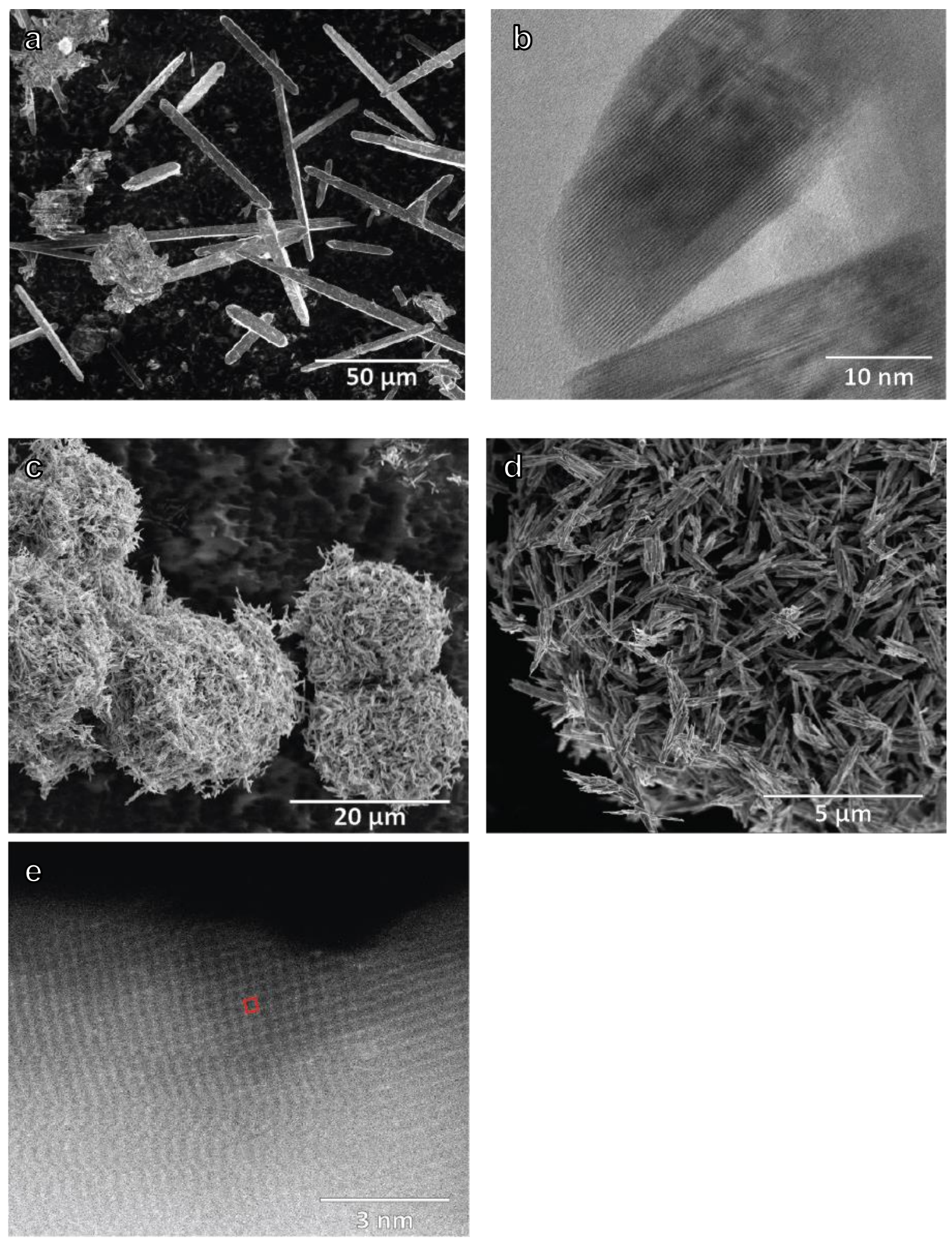

Figure S4. SEM (A, C, D) and cross-sectional TEM (B, E) of $\beta-\mathrm{MnO}_{2}-1$ and $\beta-\mathrm{MnO}_{2}-2$ : $(\mathrm{A}, \mathrm{B}) \beta-\mathrm{MnO}_{2}-1$, (C-E) $\beta$ $\mathrm{MnO}_{2}-2$. Red box in $(\mathrm{E})$ highlights the $1 \times 1$ tunnel structure of $\beta-\mathrm{MnO}_{2}-2$. 

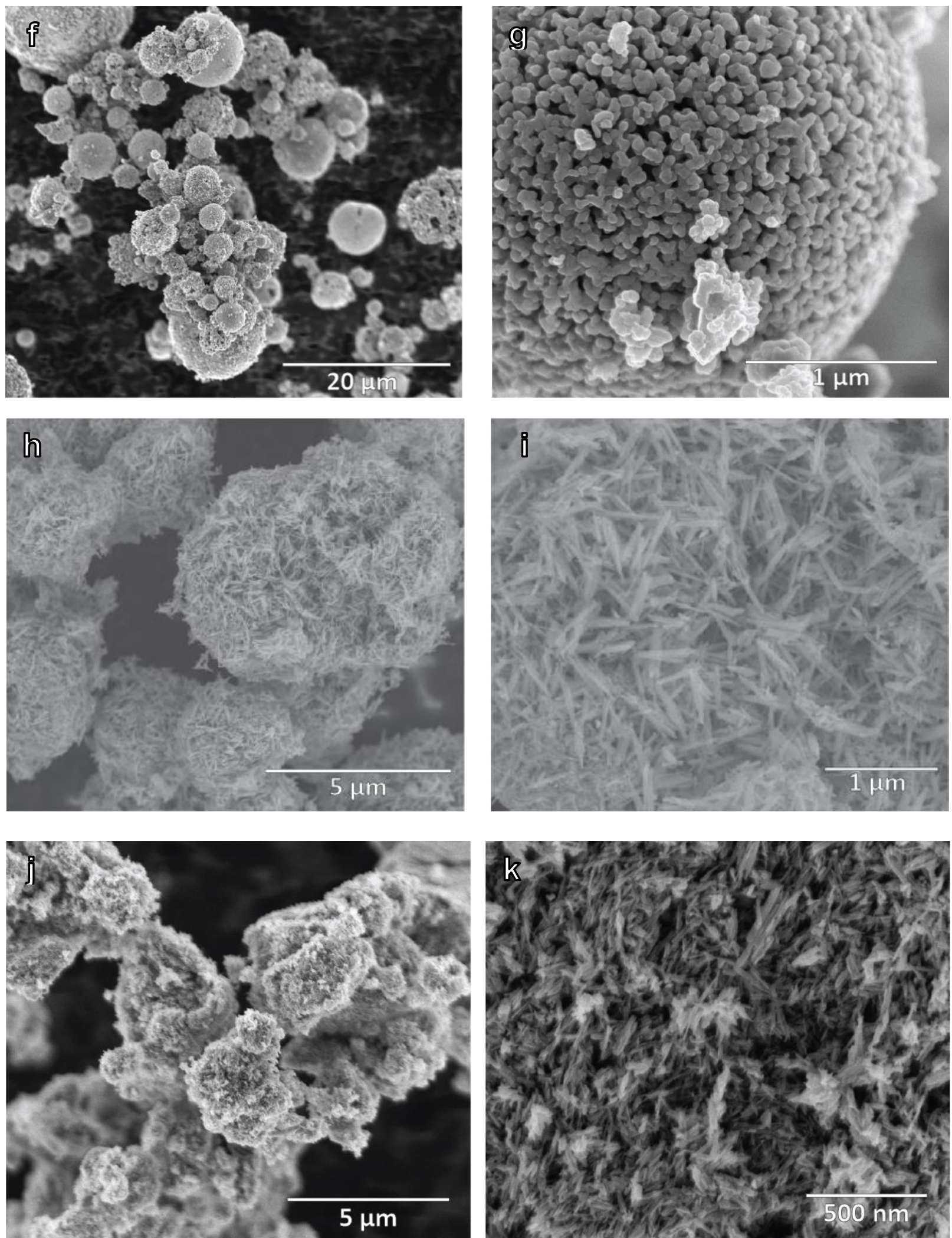

Figure S4 (continued). SEM of $\mathrm{Mn}_{2} \mathrm{O}_{3}(\mathrm{~F}, \mathrm{G}), \mathrm{y}-\mathrm{MnO}_{2}(\mathrm{H}, \mathrm{I})$, and $\alpha-\mathrm{MnO}_{2}(\mathrm{~J}, \mathrm{~K})$. 

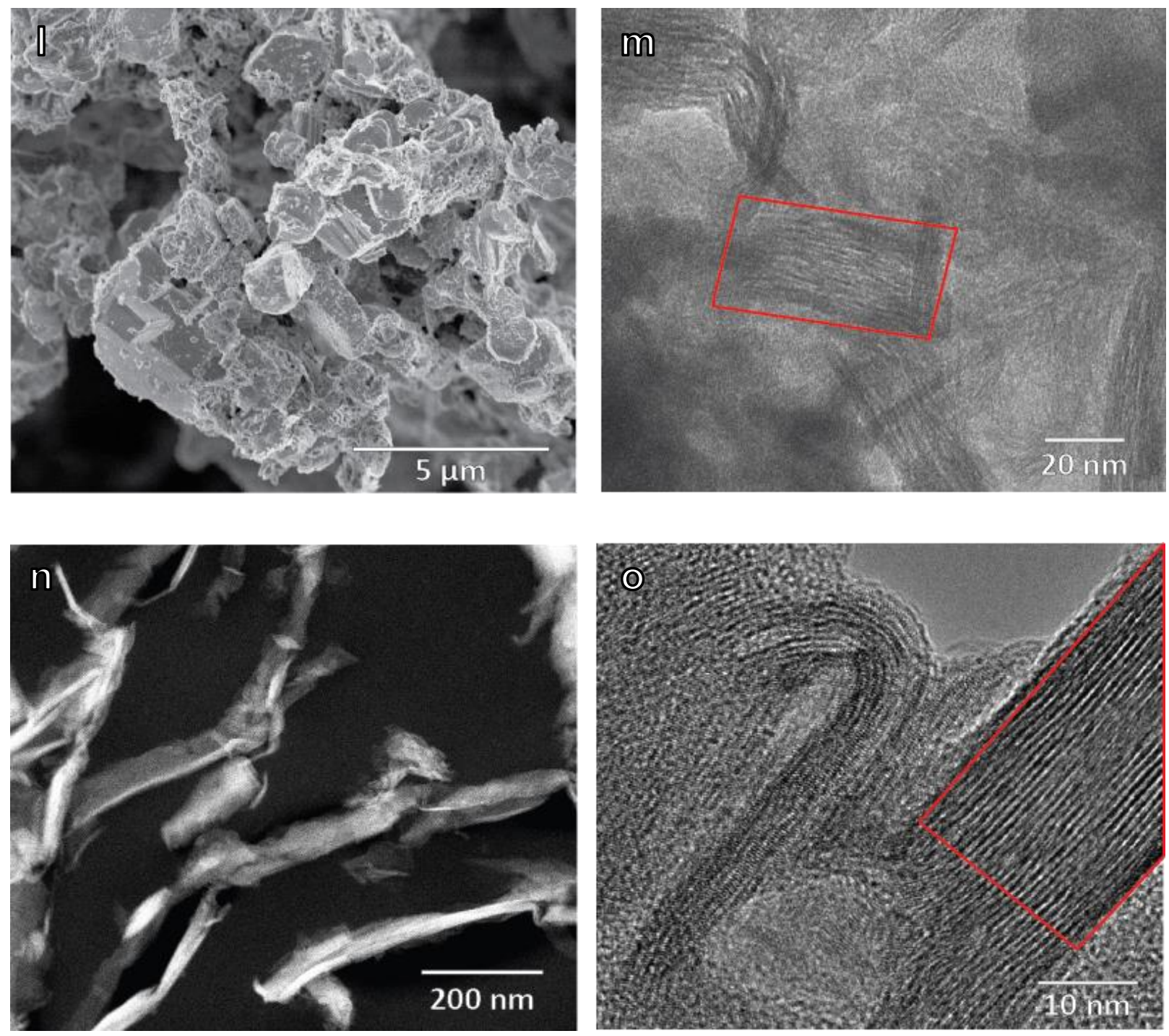

Figure S4 (continued). SEM (L) and cross-sectional TEM (M-O) of potassium birnessite and triclinic sodium birnessite: (L, M) potassium birnessite, $(\mathrm{N}, \mathrm{O})$ triclinic sodium birnessite. Red box in panels $(\mathrm{M})$ and $(\mathrm{O})$ highlight the sheet-like layers characteristic of $\delta-\mathrm{MnO}_{2} /$ birnessite structures. 

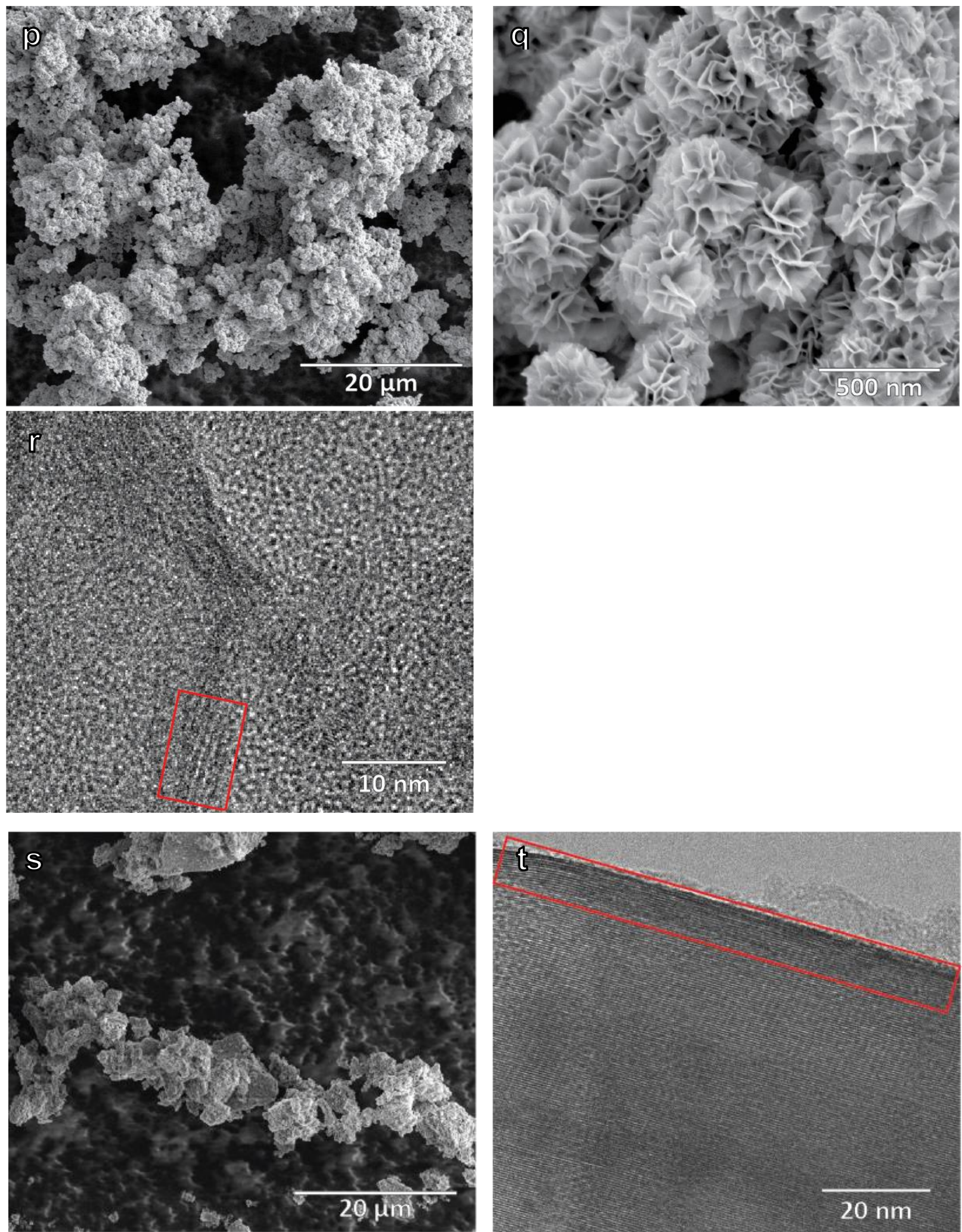

Figure S4 (continued). SEM (P, Q, S) and cross-sectional TEM (R, T) of hexagonal birnessite and $\delta-\mathrm{MnO}_{2}-1:(\mathrm{P}-\mathrm{R})$ hexagonal birnessite, $(\mathrm{S}, \mathrm{T}) \delta-\mathrm{MnO}_{2}-1$. Red box in panels $(\mathrm{R})$ and $(\mathrm{T})$ highlight the sheet-like layers characteristic of $\delta-\mathrm{MnO}_{2} /$ birnessite structures. 

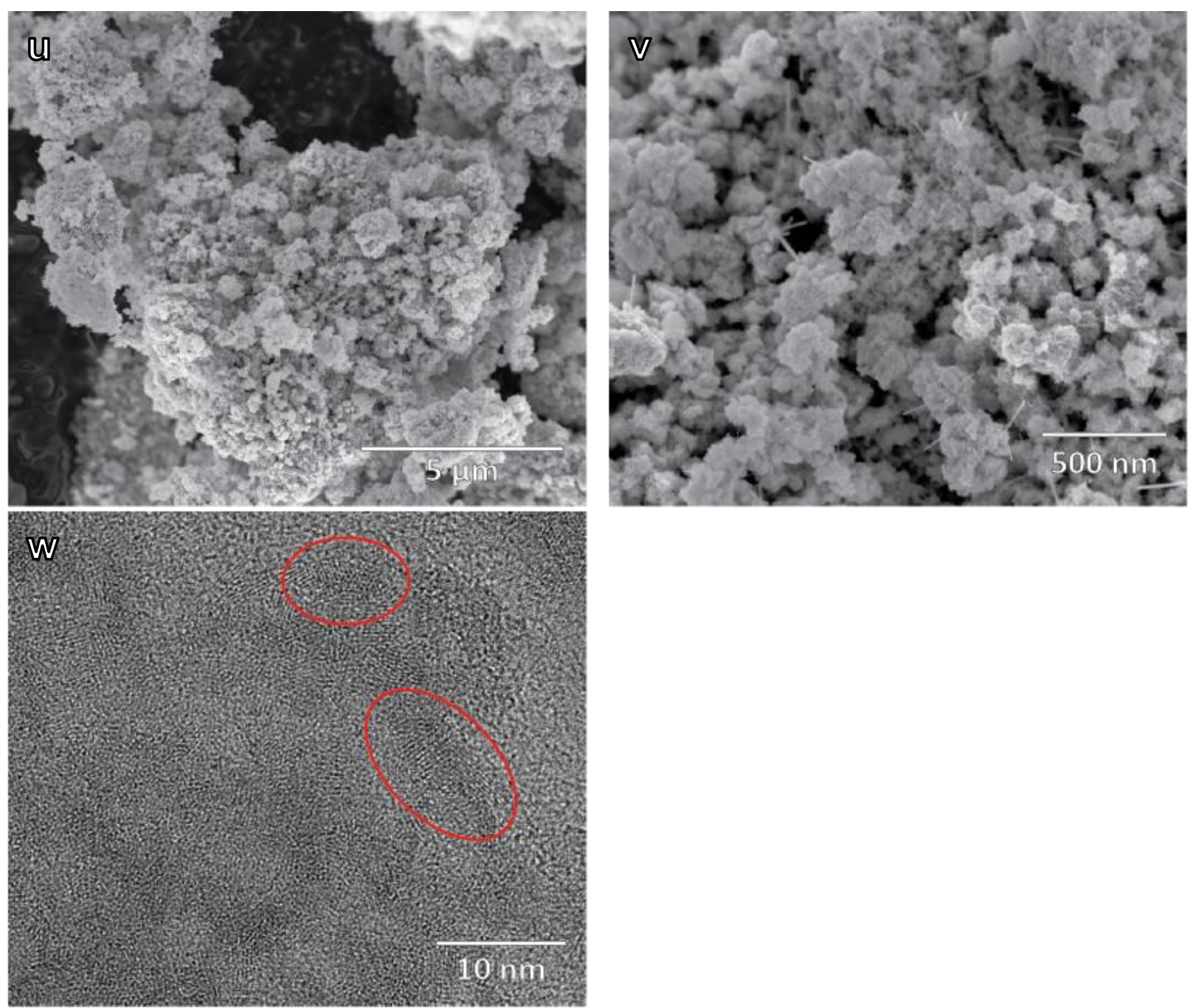

Figure S4 (continued). SEM (U, V) and cross-sectional TEM (W) of $\delta-M_{2} \mathrm{O}_{2}-2$ : Red circles in (W) highlight the nanocrystalline structures in $\delta-\mathrm{MnO}_{2}-2$. 

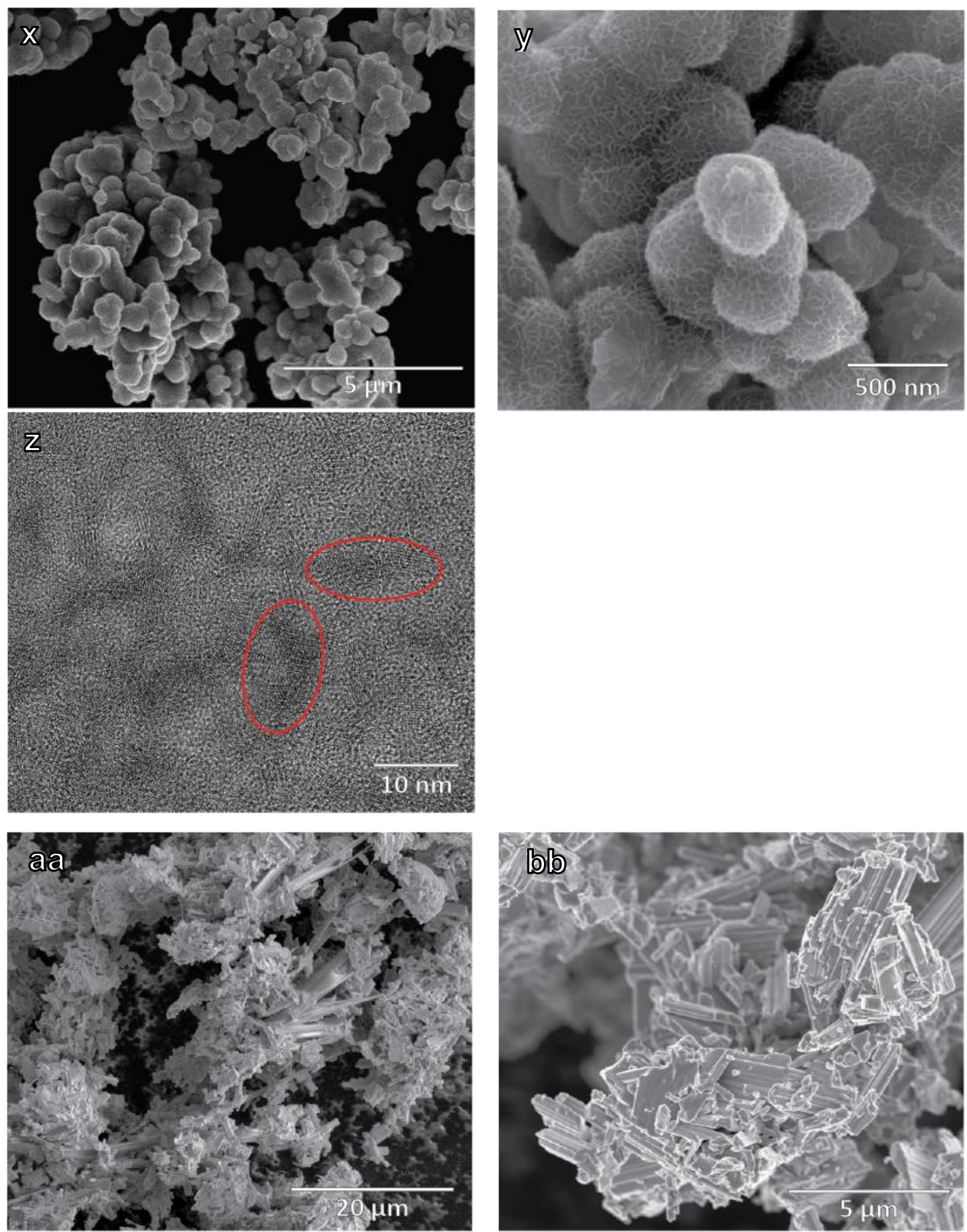

Figure S4 (continued). SEM (X, Y, AA, BB) and cross-sectional TEM (Z) of $\delta-\mathrm{MnO}_{2}-3$ and sodium manganese oxide: $(\mathrm{X}-\mathrm{Z}) \delta-\mathrm{MnO}_{2}-3,(\mathrm{AA}, \mathrm{BB})$ sodium manganese oxide. Red circles in (Z) highlight the nano-crystalline structures in $\delta-\mathrm{MnO}_{2}-3$. 


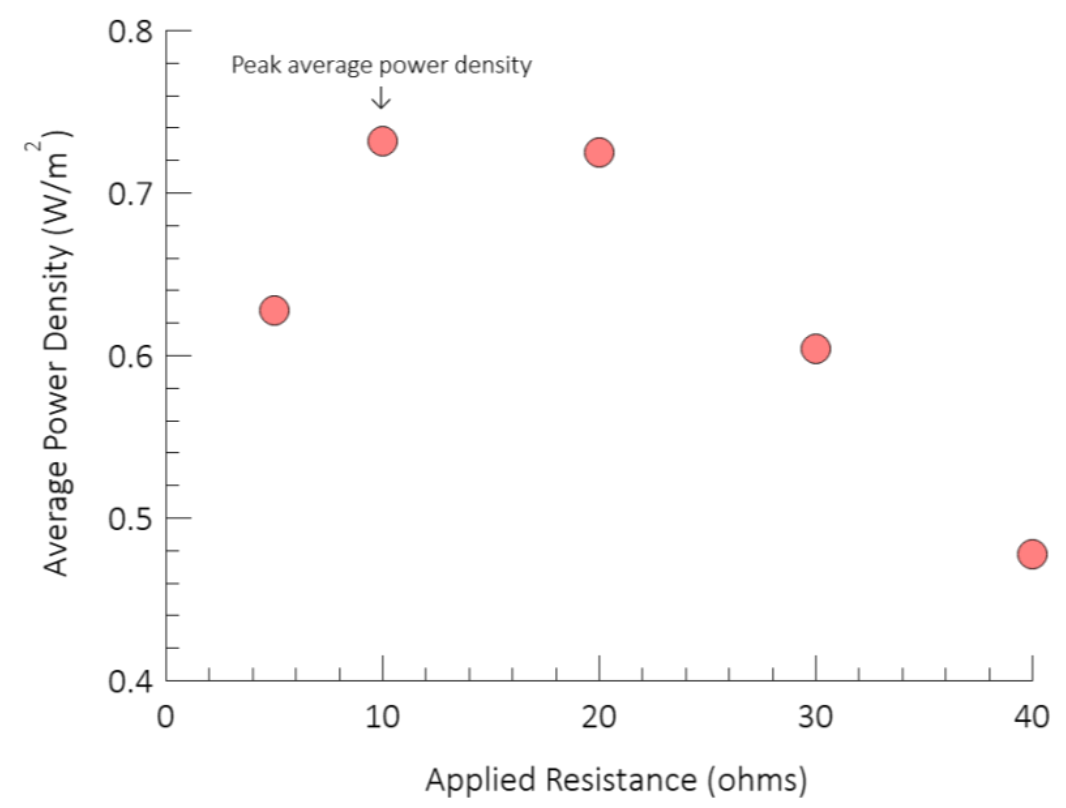

Figure S5. A representative average power density curve for $\delta-\mathrm{MnO}_{2}-3$ in the SGE concentration flow cell. Each point on the curve is generated by averaging the power density over three successive power cycles at the designated applied external resistance. The reported value is the highest point on the curve. We measured the average power densities for each manganese oxide as a function of external resistance $(5,10,20,30$, or $40 \Omega)$, with the average power density reported being the largest value measured (Table S1).

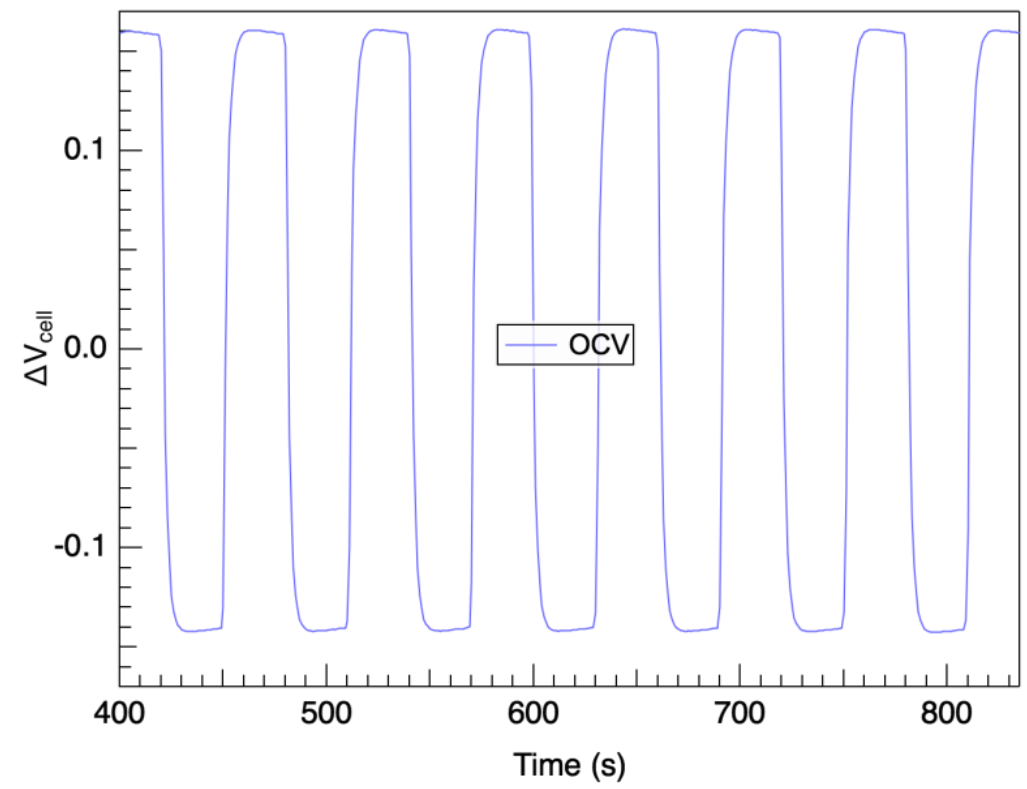

Figure S6. A representative open circuit voltage curve for $\delta-\mathrm{MnO}_{2}-2$ in the SGE concentration flow cell. 

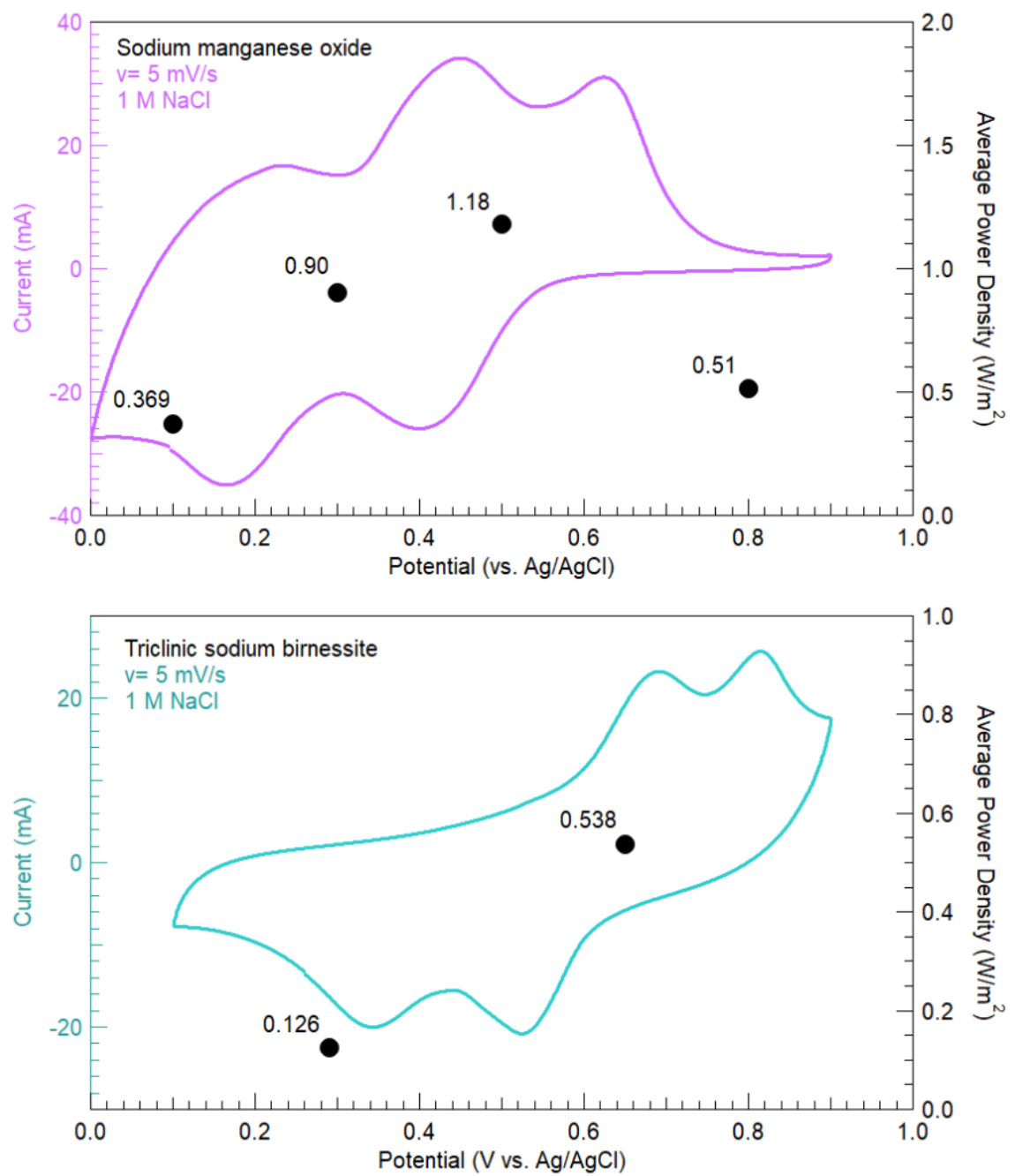

Figure S7. Cyclic voltammograms (left axis) and average power density measurements (right axis) for sodium manganese oxide (top graph) and triclinic sodium birnessite (bottom graph). Prior to measuring power in the salinity gradient flow cell, electrodes were poised at various potentials within the relevant stable potential window to show of the effects of electrode conditioning on performance. Faradaic materials (shown above) performed best when poised at the relevant midpoint potential of the faradaic redox couple. Poising (pseudo-)capacitive manganese oxides did not impact power production (data not shown). 

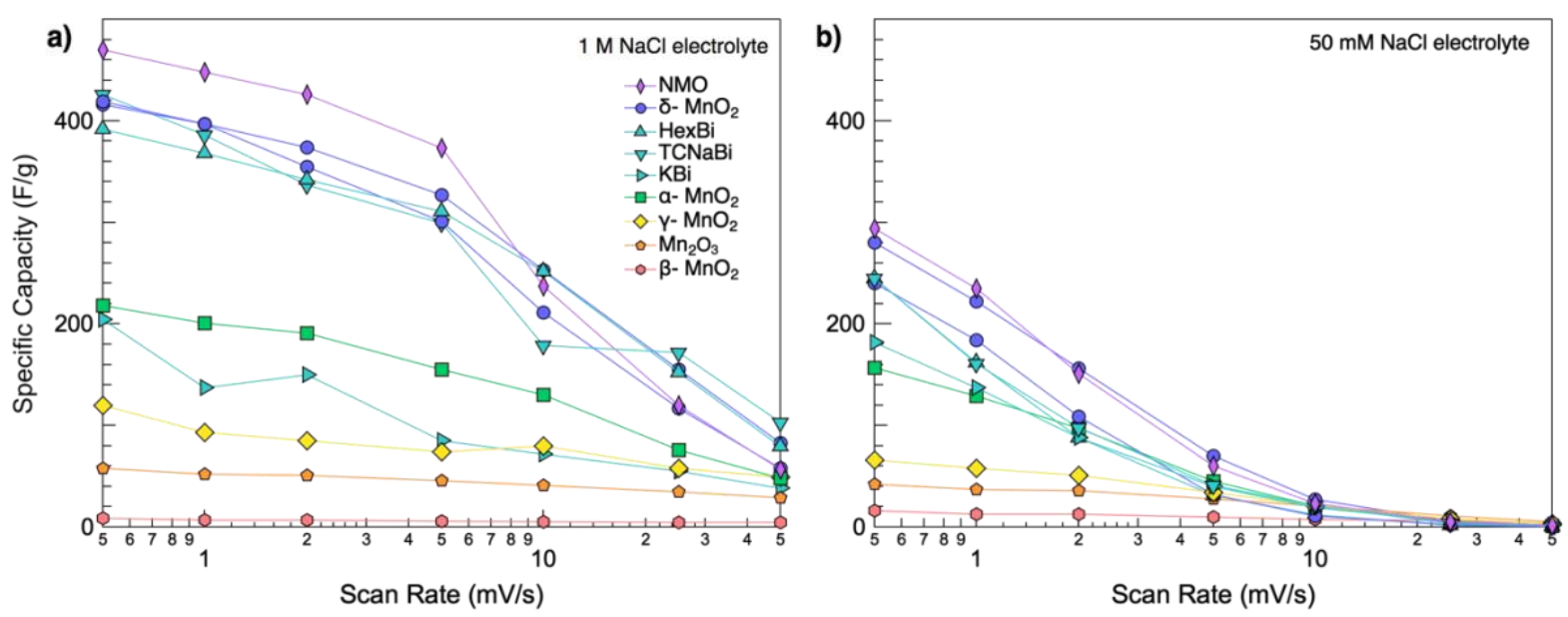

Figure S8. Specific capacity of composite manganese oxide electrodes as a function of scan rate in (a) 1 $\mathrm{M} \mathrm{NaCl}$ and (b) $50 \mathrm{mM} \mathrm{NaCl}$ electrolyte. Specific capacity was calculated by integrating the current generated during cyclic voltammetry and dividing by the mass of the manganese oxide in the electrode. 


\section{References}

(1) Musil, M.; Choi, B.; Tsutsumi, A. Morphology and Electrochemical Properties of $\alpha-, \beta-, \gamma-$, and $\delta-$ MnO2 Synthesized by Redox Method. J. Electrochem. Soc. 2015, 162 (10), A2058-A2065. https://doi.org/10.1149/2.0201510jes.

(2) Huang, J.; Zhong, S.; Dai, Y.; Liu, C. C.; Zhang, H. Effect of $\mathrm{MnO}_{2}$ Phase Structure on the Oxidative Reactivity toward Bisphenol A Degradation. Environ. Sci. Technol. 2018, 52 (19), 11309-11318. https://doi.org/10.1021/acs.est.8b03383.

(3) Pokhrel, R.; Goetz, M. K.; Shaner, S. E.; Wu, X.; Stahl, S. S. The “Best Catalyst” for Water Oxidation Depends on the Oxidation Method Employed: A Case Study of Manganese Oxides. J. Am. Chem. Soc. 2015, 137 (26), 8384-8387. https://doi.org/10.1021/jacs.5b05093.

(4) Walanda, D. K.; Lawrance, G. A.; Donne, S. W. Kinetics of $\mathrm{Mn}_{2} \mathrm{O}_{3}$ digestion in $\mathrm{H}_{2} \mathrm{SO}_{4}$ solutions. J. Solid State Chem. 2009, 182 (6), 1336-1342. https://doi.org/10.1016/j.jssc.2009.02.034.

(5) Meng, Y.; Song, W.; Huang, H.; Ren, Z.; Chen, S. Y.; Suib, S. L. Structure-Property Relationship of Bifunctional $\mathrm{MnO}_{2}$ Nanostructures: Highly Efficient, Ultra-Stable Electrochemical Water Oxidation and Oxygen Reduction Reaction Catalysts Identified in Alkaline Media. J. Am. Chem. Soc. 2014, 136 (32), 11452-11464. https://doi.org/10.1021/ja505186m.

(6) Giovanoli, R.; Stahli, E.; Feitknecht, W. Uber Oxidhydroxide Des Vierwertigen Mangans Mit Schichtengitter. Helv. Chim. Acta 1970, 53 (3), 453-464.

(7) McKenzie, R. M. The Synthesis of Birnessite, Cryptomelane, and Some Other Oxides and Hydroxides of Manganese. Mineral. Mag. 2006, 38 (296), 493-502. https://doi.org/10.1180/minmag.1971.038.296.12.

(8) Yang, P.; Lee, S.; Post, J. E.; Xu, H.; Wang, Q.; Xu, W.; Zhu, M. Trivalent Manganese on Vacancies Triggers Rapid Transformation of Layered to Tunneled Manganese Oxides (TMOs): Implications for Occurrence of TMOs in Low-Temperature Environment. Geochim. Cosmochim. Acta 2018, 240, 173-190. https://doi.org/10.1016/j.gca.2018.08.014.

(9) Liu, X.; Whitacre, J. F.; Mauter, M. S. Mechanisms of Humic Acid Fouling on Capacitive and Insertion Electrodes for Electrochemical Desalination. Environ. Sci. Technol. 2018, 52 (21), 1263312641. https://doi.org/10.1021/acs.est.8b03261.

(10) Whitacre, J. F.; Tevar, A.; Sharma, S. Na4 $\mathrm{Mn}_{9} \mathrm{O}_{18}$ as a Positive Electrode Material for an Aqueous Electrolyte Sodium-Ion Energy Storage Device. Electrochem. commun. 2010, 12 (3), 463-466. https://doi.org/10.1016/j.elecom.2010.01.020.

(11) Shanbhag, S.; Bootwala, Y.; Whitacre, J. F.; Mauter, M. S. Ion Transport and Competition Effects on $\mathrm{NaTi}_{2}\left(\mathrm{PO}_{4}\right)_{3}$ and $\mathrm{Na}_{4} \mathrm{Mn}_{9} \mathrm{O}_{18}$ Selective Insertion Electrode Performance. Langmuir 2017, 33 (44), 12580-12591. https://doi.org/10.1021/acs.langmuir.7b02861. 